\title{
Effects of Thermochemical Surface Treatments on the Industrially Important Properties of X2CrNiMo 17-12-2 Austenitic Stainless Steel
}

\author{
Dorina Kovács ${ }^{1 *}$, János Dobránszky² \\ ${ }^{1}$ Department of Materials Science and Engineering, Faculty of Mechanical Engineering, Budapest University of \\ Technology and Economics, 1111 Budapest, Múegyetem rkp. 3, Hungary \\ 2 MTA-BME Research Group for Composite Science and Technology, Faculty of Mechanical Engineering, \\ Budapest University of Technology and Economics, 1111 Budapest, Múegyetem rkp. 3, Hungary \\ * Corresponding author, e-mail: dorina@eik.bme.hu
}

Received: 22 February 2019, Accepted: 09 May 2019, Published online: 27 May 2019

\begin{abstract}
Austenitic stainless steels have low corrosion resistance in applications where strong acids and vapors attack the surface, typically in food and chemical industries. This drawback can be improved by surface treatments. Salt bath, gaseous or plasma-based surface treatments are a diffusion process for improving the hardness of the surface layer of stainless steels without significantly affecting their corrosion resistance. Low temperature nitriding and carburizing process can form a diffusion zone or/and compound phase. The corrosion-wear resistance of austenitic stainless steels can also improve with low temperature plasma nitriding and carburizing. The effect of these treatments on hardness and corrosion resistance was investigated in this research. Optical microscopy and Vickers hardness test were used for the characterization of the surface and potentiodynamic tests were performed to determine the corrosion rate. The results show that the hardness of the kolsterised sample is higher compared to the plasma nitride one. Beside this property, the corrosion rate is similar, but pitting corrosion was observed on the surface, due to the $\mathrm{Cr}_{2} \mathrm{~N}$ formation.
\end{abstract}

Keywords

plasma nitriding, kolsterising, austenitic stainless steel, corrosion rate

\section{Introduction}

Nowadays, the improvement of the corrosion-wear resistance of stainless steels is becoming popular research area in the industrial applications. Low temperature nitriding (below $450{ }^{\circ} \mathrm{C}$ ) is one of the most widely used surface treatment process in order to improve the surface hardness and wear resistance of steels without the loss of corrosion resistance $[1,2]$. During the nitriding process, so-called expanded austenite can be formed on the surface of the austenitic stainless steels [3]. The precipitation of chromium nitrides in the nitrided layer can be suppressed, such that a nitrogen supersaturated layer composed of a metastable phase, which is known as S-phase $[4,5]$. In this case, the nitrogen is an interstitial atom in the austenite's face centered cubic lattice. The S-phase can occur in the patented kolsterising process, where the nitrogen is replaced by carbon.

The kolsterising is a low temperature carburizing (below approx. $500{ }^{\circ} \mathrm{C}$ ) process of austenitic stainless steels in which the carbon is dissolved interstitially in the austenitic lattice without forming any chromium carbides [6-8]. The process developed by Kolster, which is proprietary technology of Bodycote Heat Treatment. Faccoli et al. [9] mentioned the process results a hard diffusion layer on the surface with 6-7 w\% carbon content increase, but Farrell et al. [10] measured 3-4.5 w\%. They used kolsterising in their research that can produce different layer thicknesses on the surface such as $22 \mu \mathrm{m}$ and $33 \mu \mathrm{m}$. The concentration of carbon in the layer will decrease with depth, likewise the hardness. The carbon is not simply contained in the expanded lattice, but also as iron carbide in non-uniformly distributed near the surface. After the treatment, the surface was wrinkled and the grain boundaries were strongly demarked [10]. Kolsterising can prove the corrosion resistance over the untreated materials not only in commonly used stainless steels, but also in biomedical steels. Formosa et al. [11] used in their research a Ni-free medical grade steel (DIN 1.3808) and 
AISI 304. The kolsterising was performed at a temperature below $500{ }^{\circ} \mathrm{C}$ for several days duration. The formed layers were about $30 \mu \mathrm{m}$ thick in both materials. The hardness of the kolsterised layer was the double (594HV0.05) in the Ni-free alloy and the triple (942HV0.05) in the AISI 304 grade, compared to the untreated base material. It can be seen, the two materials had different responses to the treatment, which can be observed in the results of the chemical analysis. The carbon content of the AISI 304 alloy was the half $(0.08 \%)$ of the other, the hardness was better, but the weight loss during the corrosion tests was higher. The medical steel has relatively low sulphur content $(0.01 \mathrm{w} \%)$ in comparison to the industrially used stainless steels $(0.05 \%)$, therefore AISI 304 has a higher $\mathrm{MnS}$ inclusion content than any medical stainless steel. The wear resistance was not examined [11].

However, Rey and Jacquot [7] investigated the wear resistance of the kolsterised surface. The wear resistance increased after the treatment, while the surface roughness of the treated parts almost remained during the wear tests, but the untreated samples increased significantly [7].

According to Collins et al. [12], the untreated material suffered from severe plastic deformation during the test, while the carburized material did not. The carburized surface showed minor surface wear debris while the untreated part indicates stick-slip phenomenon [12].

The aim of this research is to compare different types of surface treatment of such tools, which are used in industrial conditions where corrosion-wear is the main damaging effect.

\section{Materials and methods}

AISI 316L type austenitic stainless steel was used for the experiments with the following chemical composition (in wt\%.): Cr (16.7), Ni (9.84), Mo (1.95), C (0.02), and Fe for balance. The treatments were carried out as listed in Table 1.

Higher corrosion resistance can be reached by using a leading industrial passivation process of stainless steels. The corrosion resistance is primarily attributed to the passive film formed on the surface [13, 14]. This process is a chemical treatment which removes free iron and

Table 1 Surface conditions of the samples

\begin{tabular}{lc}
\hline Sample No. & Surface condition \\
\hline $\mathrm{P}$ & passivated \\
$\mathrm{PN}$ & passivated + plasma nitrided \\
$\mathrm{K}$ & passivated + kolsterised \\
$\mathrm{K}+\mathrm{P}$ & passivated + kolsterised + passivated \\
\hline
\end{tabular}

contaminants from the surface, while simultaneously promoting the formation of a passive chromium oxide rich layer [15]. In this research this process was done in nitric acid for 30 minutes. The direct current plasma nitriding was performed at $500{ }^{\circ} \mathrm{C}$ in a $75 \% \mathrm{~N}_{2}+25 \% \mathrm{H}_{2}$ gas mixture for 12 hours. After completing the process, the sample was slowly cooled to room temperature in the chamber. The low temperature carburizing was performed at the industrial provider of the kolsterising treatment.

The surface hardness was measured by hardness tester (Buehler IndentaMet 1105). For the microstructural investigations Olympus PMG 3 optical microscope was used. The corrosion resistance of the samples was evaluated by measuring polarization curves in $1 \mathrm{M} \mathrm{H}_{3} \mathrm{PO}_{4}$ solution using ZAHNES IM6e electrochemical working station. The cell of the specimen was set-up as the working electrode, $\mathrm{a}_{2} \mathrm{Cl}_{2}$ / KCltel calomel electrode as the reference electrode and a platinum was used as the counter electrode. The morphology of the corroded sample's surface was observed by Olympus SZX16 stereomicroscope and Zeiss EVO MA10 scanning electron microscope (SEM).

\section{Results and discussion}

\subsection{Microstructural investigation}

The microstructure of the substrate and the modified surface layer are presented in Fig. 1. As it is observed in Fig. 1 a), there are extended sulphide inclusions in the substrate. The microstructure of the austenite cannot be seen well in the other pictures, because of preventing an overetching of the layer.

The presence of $\mathrm{Cr}_{2} \mathrm{~N}$, due to the higher plasma nitriding temperature $\left(>450{ }^{\circ} \mathrm{C}\right)$, which compound is uniformly dark after the etching, can be seen in Fig. 1 b), while the expanded austenite is white [16, 17]. It is seen in Fig. 1 c), d), that the kolsterised layer is homogeneous along the cross-section in both cases. These layers thickness is about $30 \mu \mathrm{m}$, which refers on the process of Bodycote. Any thickness-changing effect of the passivation is not observed.

\subsection{Microhardness testing}

The hardness of the treated samples was measured in two ways, once perpendicularly on the flat of the surface to determine the maximum hardness, at the second time on the cross-section to analyze the profile. Fig. 2 shows the hardness profile of the treated samples. In all cases the average of three measurements is presented. Likewise, for the layer thicknesses of each treatment, the hardness profile is slightly different. 

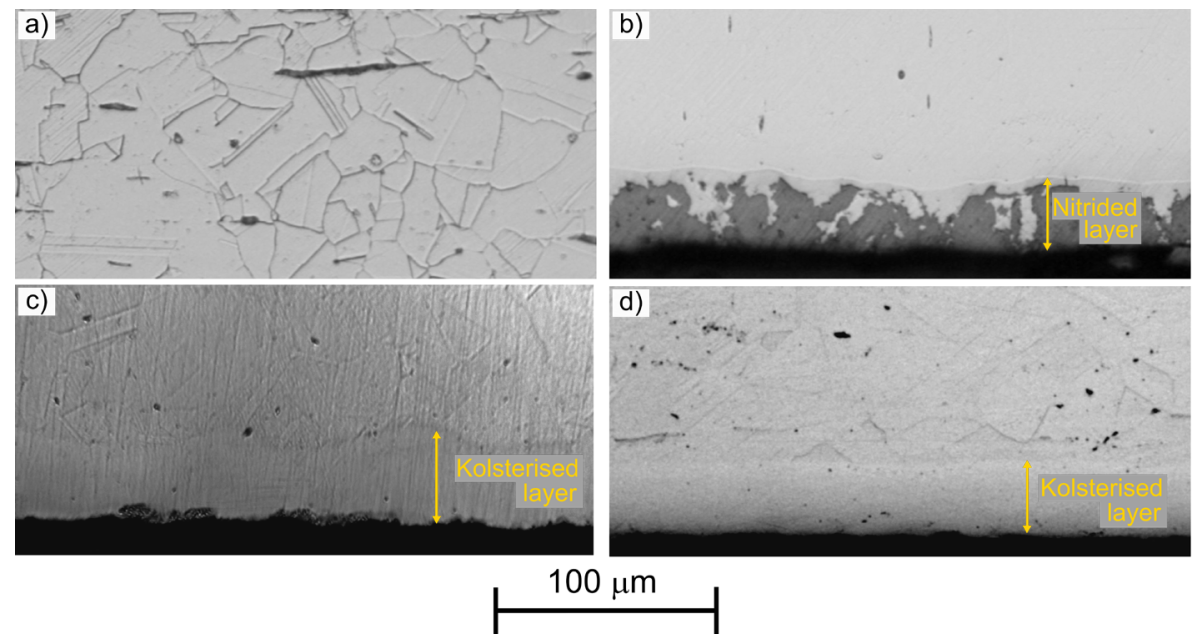

Fig. 1 Cross-section optical microscopic images of samples etched with Aqua Regia. a) sample P, b) sample PN, c) sample K, d) sample K + P

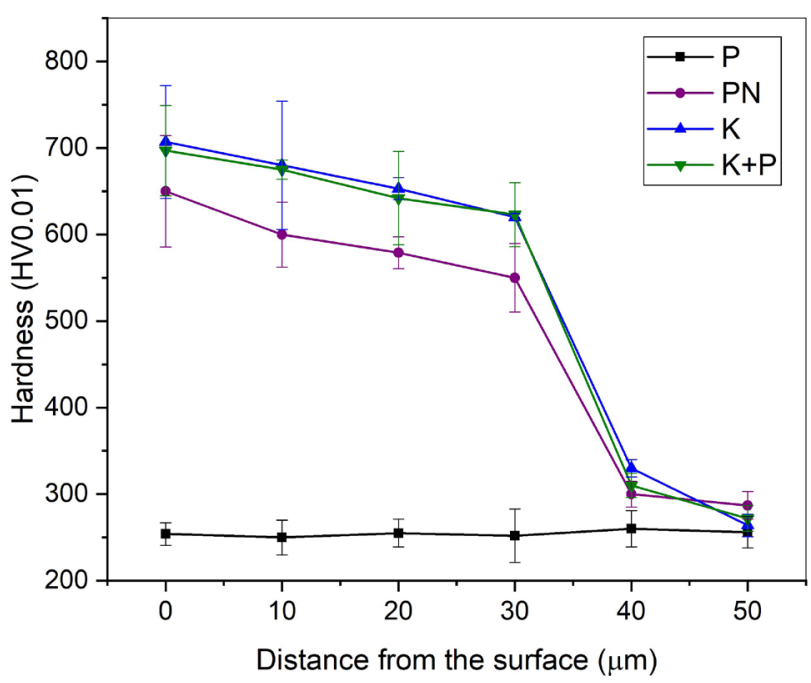

Fig. 2 Hardness profiles of treated samples

Fig. 3 shows the maximum measured hardness of the samples. Differences can be found in the maximum hardness. The base hardness of the substrate is the same of the only-passivated sample, 250 HV0.01. The kolsterised sample has the maximum hardness (700 HV0.01), while the hardness of the plasma nitrided sample was 50 HV0.01 less.

The maximum hardness of the kolsterised sample is different from the results in previous researches in which 1000-1200 HV0.01 was measured [18, 19].

\subsection{Corrosion behavior}

Generally, the main corrosion form of the austenitic steel is pitting corrosion [20-22]. Fig. 4 shows the results of the potentiodynamic polarization test of the samples. Neither the corrosion potential, nor the current density of the samples considerably changed. A slight fluctuation,

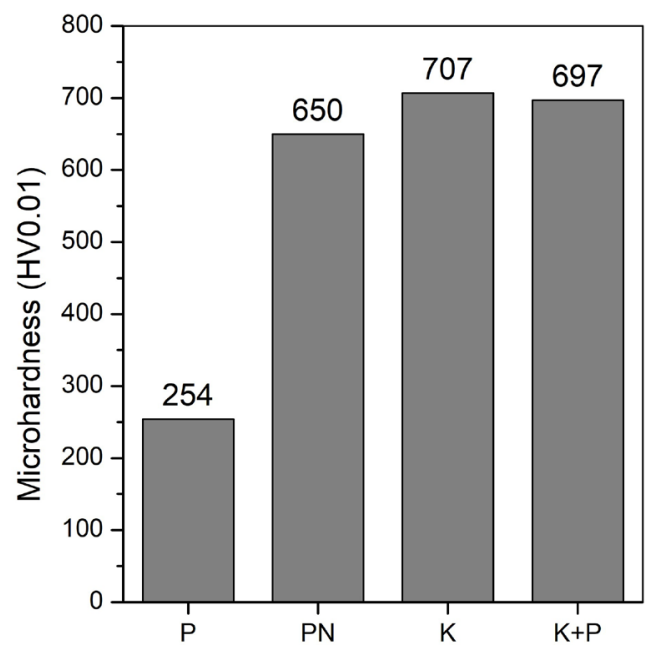

Fig. 3 Maximum hardness of the treated samples

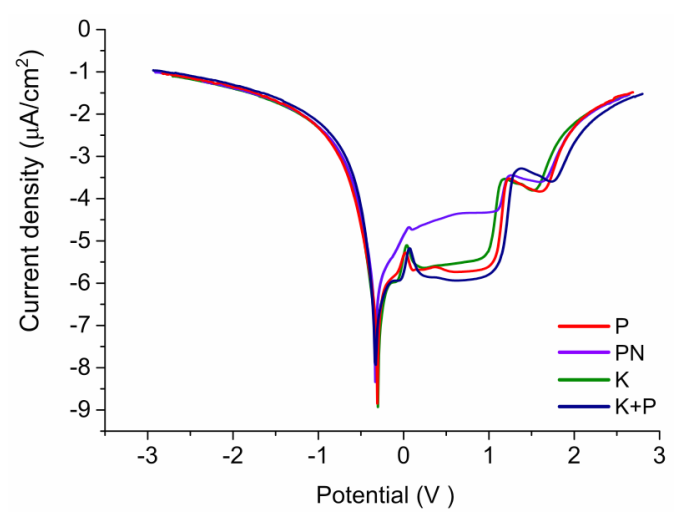

Fig. 4 Polarization curves of treated samples after 24 hours

due to the different treatments, can be observed. The plasma nitrided sample has lower corrosion rate than the kolsterised has. The passivation after the kolsterising did not cause significant improvement in corrosion resistance. 
The calculated corrosion rate [23] parameters are listed in Table 2.

The passivated sample has a good corrosion resistance, however the corrosion started at $0.2 \mathrm{~V}_{\text {(SCE) }}$ and ended at $0.4 \mathrm{~V}_{\text {(SCE), }}$, following with a passivation area $\left(0.9-1.4 \mathrm{~V}_{(\mathrm{SCE})}\right)$. The corrosion rate of the treated samples is similar. The surfaces were passivated at the same potential range. The nitrided sample has a higher corrosion resistance in phosphoric acid according to the Tafel curves, but pitting was observed on the surface. The possible reason for this is the formation of the $\mathrm{Cr}_{2} \mathrm{~N}$ that can be found on the top of the layer. The corrosion attacked only this part but did not reach the substrate. The development of chromium nitrides leads inevitably to loss of the corrosion performance of stainless steel, because chromium is removed from solid solution in the matrix [24].

\subsection{Operational testing}

The original product is seen in Fig. 5 and Fig. 6 shows the results of the operational testing 2 months after the installation. The testing of the specimens was performed by the industrial provider (bottler company of cola beverage).

Table 2 Corrosion rate parameters of the treated samples

\begin{tabular}{lccc}
\hline Sample & $\begin{array}{c}E_{\text {corr }} \\
(\mathrm{V})\end{array}$ & $\begin{array}{c}i_{\text {corr }} \\
\left(\mu \mathrm{A} / \mathrm{cm}^{2}\right)\end{array}$ & $\begin{array}{c}\text { Corrosion rate } \\
(\mathrm{mm} / \text { year })\end{array}$ \\
\hline $\mathrm{P}$ & 0.432 & 3.5 & 0.03846 \\
$\mathrm{PN}$ & 0.177 & 3.309 & 0.03402 \\
$\mathrm{~K}$ & 0.409 & 3.618 & 0.03742 \\
$\mathrm{~K}+\mathrm{P}$ & 0.618 & 3.048 & 0.03152 \\
\hline
\end{tabular}

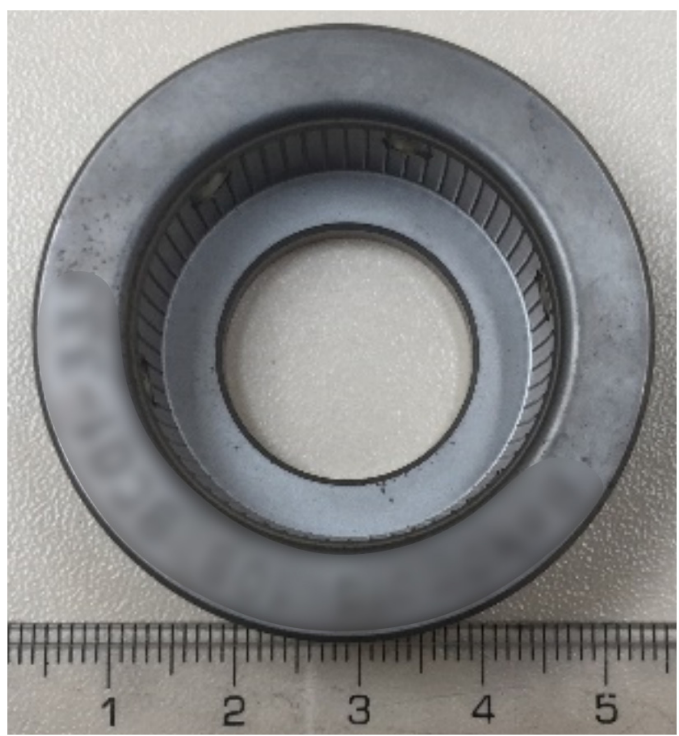

Fig. 5 Original product
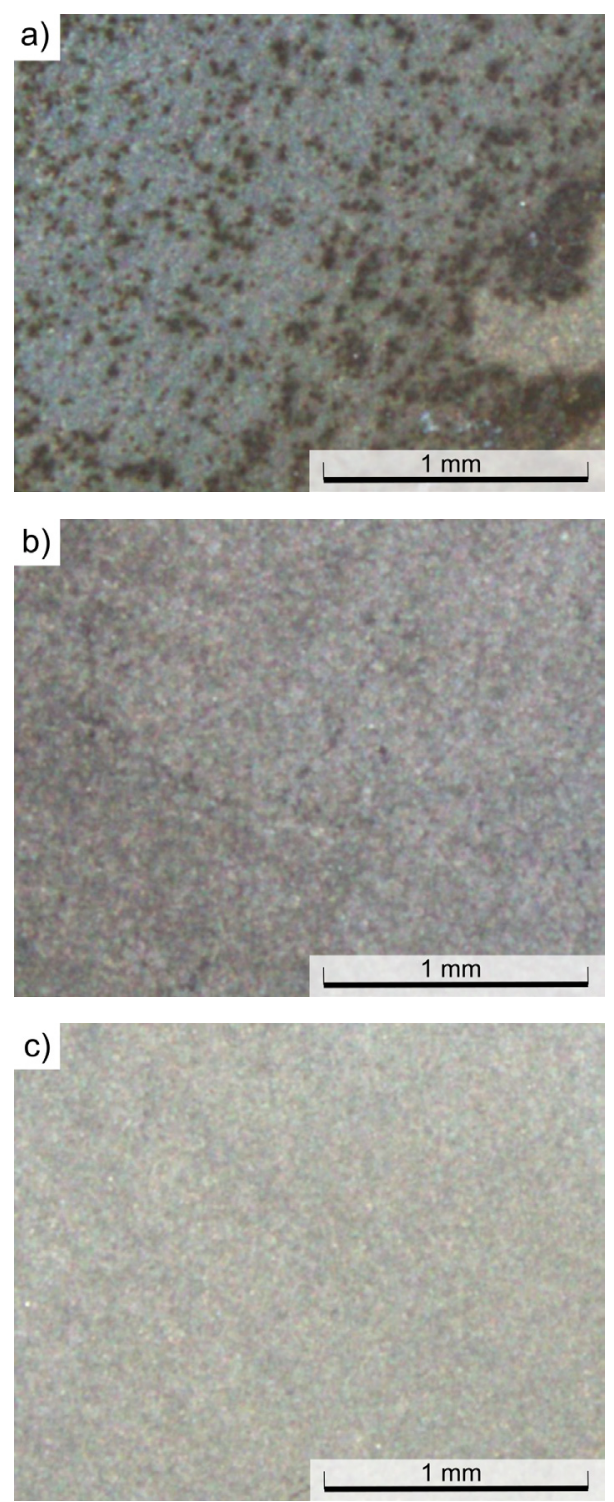

Fig. 6 Surface of the treated samples after operational testing. a) sample PN, b) sample K, c) sample K + P

The kolsterised samples have a similar behavior during the operational testing then during the corrosion testing. Contaminants and corrosion patches were not observed (Fig. 6 b), c)) contrarily the plasma nitrided sample.

Corrosion patches were covered all the plasma nitrided samples. There were on corrosion pits as it was seen after the corrosion test. SEM-EDS was used to determine the contaminants on the surface (Fig. 7).

The numbers and arrows mark the point of the EDSmicroanalysis in each point the chemical composition was similar. The main elements in the corrosion product are oxygen $(\mathrm{O})$ and iron $(\mathrm{Fe})$, but the chromium and nickel content were much lower than that of the base material. This composition is typical in the rust on the surface of 


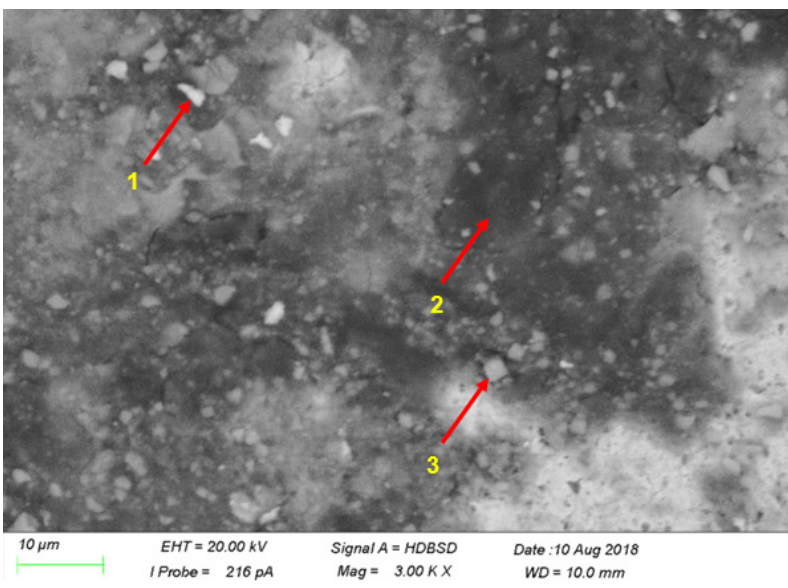

Fig. 7 Analyzed points of the corroded part of the plasma nitride sample

stainless steels ("rust" is a standard term: visible corrosion products consisting mainly of hydrated iron oxides which is not equal with any of iron oxides [25]). The significant amount of elements such as $\mathrm{Na}, \mathrm{Al}, \mathrm{K}$ and especially the $\mathrm{Cl}$, shows that the contamination also had to contain some strong corrosive agents.

\section{References}

[1] Saeed, A., Khan, A. W., Jan, F., Waqar, M., Abrar, M., Mujahid, Z.-U.-I., Hussnain, A., Zakaullah, M. "Pulsed dc Discharge in the Presence of Active Screen for Nitriding of High Carbon Steel", Materials Research, 17(4), pp. 857-865, 2014. https://doi.org/10.1590/1516-1439.242713

[2] Sun, Y., Li, X. Y., Bell, T. "X-ray diffraction characterisation of low temperature plasma nitrided austenitic stainless steels", Journal of Materials Science, 34(19), pp. 4793-4802, 1999. https://doi.org/10.1023/A:1004647423860

[3] Li, C. X., Bell, T. "Corrosion properties of active screen plasma nitrided 316 austenitic stainless steel", Corrosion Science, 46(6), pp. 1527-1547, 2004

https://doi.org/10.1016/j.corsci.2003.09.015

[4] Fossati, A., Borgioli, F., Galvanetto, E., Bacci, T. "Glow-discharge nitriding of AISI 316L austenitic stainless steel: Influence of treatment time", Surface and Coatings Technology, 200(11), pp. 3511-3517, 2006.

https://doi.org/10.1016/j.surfcoat.2004.10.122

[5] Sun, Y., Bell, T. "Low Temperature Plasma Nitriding Characteristics of Precipitation Hardening Stainless Steel", Surface Engineering, 19(5), pp. 331-336, 2003. https://doi.org/10.1179/026708403225007545

[6] McClintock, D. A., Hyres, J. W., Vevera, B. J. "Hardness and stability of a carburized surface layer on AISI 316L stainless steel after irradiation in a spallation neutron environment", Journal of Nuclear Materials, 450(1-3), pp. 176-182, 2014. https://doi.org/10.1016/j.jnucmat.2014.01.005

[7] Rey, O., Jacquot, P. "Kolsterising: hardening of austenitic stainless steel", Surface Engineering, 18(6), pp. 412-414, 2002. https://doi.org/10.1179/sur.2002.18.6.412

\section{Conclusion}

The kolsterising and the plasma nitriding is an effective surface treatment to increase the hardness of austenitic stainless steel without decreasing their corrosion resistance. Similar layer thicknesses were formed on the surface in both treatments. The surface hardness of the kolsterised sample is $50 \mathrm{HV}$ higher than the nitrided. The corrosion rates of the samples are similar. The passivation after the kolsterising did not influence the results. According to our results it can be stated, that the kolsteristed sample has higher hardness and better corrosion resistance compared to the plasma nitride and/or passivated ones.

\section{Acknowledgement}

The authors are grateful to the foundation of Richter Gedeon Talentum for supporting this research. The research was also supported by the BME-Nanonotechnology FIKP grant of EMMI (BME FIKP-NAT).

[8] Gümpel, P., Wägner, M. "Improving hardness and wear resisstance of austenitic basic conditions", MTZ worldwide, 71(9), pp. 50-53, 2010.

https://doi.org/10.1007/BF03227046

[9] Faccoli, M., Cornacchia, G., Roberti, R., Bordiga, V. "Effect of Kolsterising treatment on surface properties of a duplex stainless steel", La Metallurgia Italiana, (4), pp. 13-18, 2012.

[10] Farrell, K., Specht, E. D., Pang, J., Walker, L. R., Rar, A., Mayotte, J. R. "Characterization of a carburized surface layer on an austenitic stainless steel", Journal of Nuclear Materials, 343(1-3), pp. 123-133, 2005.

https://doi.org/10.1016/j.jnucmat.2004.10.169

[11] Formosa, D., Hunger, R., Spiteri, A., Dong, H., Sinagra, E., Buhagiar, J. "Corrosion behaviour of carbon S-phase created on Ni-free biomedical stainless steel", Surface and Coatings Technology, 206(16), pp. 3479-3487, 2012. https://doi.org/10.1016/j.surfcoat.2012.02.020

[12] Collins, S. R., Williams, P. C., Marx, S. V., Heuer, A., Ernst, F., Kahn, H. "Low-Temperature Carburization of Austenitic Stainless Steels", In: Dossett, J. L., Totten, G. E. (eds.) Heat Treating of Irons and Steels, Vol. 4D, ASM Handbook, ASM International, Materials Park, OH, USA, 2014, pp. 451-460. https://doi.org/10.31399/asm.hb.v04d.a0005939

[13] Yao, J., Macdonald, D. D., Dong, C. "Passive film on 2205 duplex stainless steel studied by photo- electrochemistry and ARXPS methods", Corrosion Science, 146, pp. 221-232, 2019. https://doi.org/10.1016/j.corsci.2018.10.020

[14] Olsson, C. O. A. "Passivation of Stainless Steels and Other Chromium Bearing Alloys", In: Wandelt, K. (ed.) Encyclopedia of Interfacial Chemistry: Surface Science and Electrochemistry, Elsevier, Oxford, UK, 2018, pp. 357-364. https://doi.org/10.1016/B978-0-12-409547-2.13585-1 
[15] Noh, J. S., Laycock, N. J., Gao, W., Wells, D. B. "Effects of nitric acid passivation on the pitting resistance of 316 stainless steel", Corrosion Science, 42(12), pp. 2069-2084, 2000. https://doi.org/10.1016/S0010-938X(00)00052-4

[16] Bielawski, J., Baranowska, J., Szczecinski, K. "Microstructure and properties of layers on chromium steel", Surface and Coatings Technology, 200(22-23), pp. 6572-6577, 2006. https://doi.org/10.1016/j.surfcoat.2005.11.037

[17] de Sousa, R. R. M., de Araújo, F. O., da Costa, J. A. P., de S. Brandim, A., de Brito, R. A., Alves Jr., C. "Cathodic Cage Plasma Nitriding: An Innovative Technique", Journal of Metallurgy, 2012, article ID: 385963, 2012. https://doi.org/10.1155/2012/385963

[18] van der Jagt, R. H., Kolster, B. H., Gillham, M. W. H. "Anti-wear / corrosion treatment of finished austenitic stainless steel components: the Hardcor process", Materials \& Design, 12(1), pp. 41-46, 1991. https://doi.org/10.1016/0261-3069(91)90091-H

[19] Bos, M. J. "Case hardening of austenitic stainless steel pump components", World Pumps, 1998(378), pp. 30-34, 1998. https://doi.org/10.1016/S0262-1762(99)80557-4

[20] Varbai, B., Pickle, T., Májlinger, K. "Development and Comparison of Quantitative Phase Analysis for Duplex Stainless Steel Weld", Periodica Polytechnica Mechanical Engineering, 62(3), pp. 247-253, 2018

https://doi.org/10.3311/PPme.12234
[21] Fazakas, É., Wang, J. Q., Zadorozhnyy, V., Louzguine-Luzgin, D. V., Varga, L. K. "Microstructural evolution and corrosion behavior of $\mathrm{Al}_{25} \mathrm{Ti}_{25} \mathrm{Ga}_{25} \mathrm{Be}_{25}$ equi-molar composition alloy", Materials and Corrosion, 65(7), pp. 691-695, 2014. https://doi.org/10.1002/maco.201206941

[22] Horicsányi, K., Asztalos, L., Károly, D., Fazakas, É. "Effect of Expansion Pressure on the Drug Eluting Coating and the Corrosion Characteristics of Coronary Stents", Acta Materialia Transylvanica, 1(1), pp. 37-40, 2018. https://doi.org/10.2478/amt-2018-0012

[23] McCafferty, E. "Validation of corrosion rates measured by the Tafel extrapolation method", Corrosion Science, 47(12), pp. 3202-3215, 2005. https://doi.org/10.1016/j.corsci.2005.05.046

[24] Somers, M. A. J., Christiansen, T. L. "14 - Low temperature surface hardening of stainless steel", In: Mittemeijer, E. J., Somers, M. A. J. (eds.) Thermochemical Surface Engineering of Steels: Improving Materials Performance, Woodhead Publishing Series in Metals and Surface Engineering, 2nd ed., Woodhead Publishing Limited, Oxford, UK, 2015, pp. 557-579. https://doi.org/10.1533/9780857096524.4.557

[25] International Organization for Standardization "ISO 8044:2015 Corrosion of metals and alloys - Basic terms and definitions", ISO, Geneva, Switzerland, 2015. 